九州大学学術情報リポジトリ

Kyushu University Institutional Repository

\title{
Infestation caused by the Agromyzid Leafminer Liriomyza trifolii of Bean Crops in Kafr EL- Shiekh, Egypt
}

Bassiony, Rowfida A.

Institute of Biological Control, Faculty of Agriculture, Kyushu University | Plant Protection Research Institute | Institute of Biological Control, Faculty of Agriculture, Kyushu University

Abou-Attia, F. A.

Economic Entomology Department, Faculty of Agriculture, Kafrelsheikh University

Samy, M. A.

Plant Protection Research Institute | Institute of Biological Control, Faculty of Agriculture, Kyushu University

Youssef, Asmhan E.

Economic Entomology Department, Faculty of Agriculture, Kafrelsheikh University | Institute of Biological Control, Faculty of Agriculture, Kyushu University

他

https://doi.org/10.5109/1854017

出版情報：九州大学大学院農学研究院紀要. 62 (2)，pp.435-438，2017-09-08. Faculty of Agriculture, Kyushu University

バージョン：

権利関係 : 


\title{
Infestation caused by the Agromyzid Leafminer Liriomyza trifolii of Bean Crops in Kafr EL-Shiekh, Egypt
}

\section{Rowfida A. BASSIONY ${ }^{1,2}$, F. A. ABOU-ATTIA ${ }^{3}$, M. A. SAMY ${ }^{2}$, Asmhan E. YOUSSEF ${ }^{3}$ and Takatoshi UENO ${ }^{1}$}

\author{
Institute of Biological Control, Faculty of Agriculture, Kyushu University, Fukuoka 812-8581, Japan \\ (Received April 28, 2017 and accepted May 10, 2017)
}

\begin{abstract}
Dipteran leafminers of the family Agromyzidae are polyphagous pests that evoke a severe worldwide threat to various vegetable crops. In Egypt, legume yields have recently been reduced due to intensive infestations by the leafminers. In the present study, we examined the composition of dipteran leafminers in two main leguminous crops, i.e., broad bean and snap bean, and evaluated the damage caused by them, in Kafr EL-Shiekh, Egypt. Liriomyza trifolii was the major leafminer species abundantly found on both crops while Melanagromyza phaseoli was found only in snap bean field with low density. Liriomyza trifolii was detected throughout the growing season of bean plants, though the population and infestation levels were significantly low in snap bean. A higher level of infestation on broad bean suggested the presence of host plant preference in the leafminer. Precipitation appeared to affect the infestation level of the leafminer. We discuss the importance of leafminer management in bean fields in Egypt.
\end{abstract}

Key words: Population fluctuation, bean fly, abiotic factors, pest management

\section{INTRODUCTION}

Legumes are of a special importance as staple food worldwide and are therefore cultivated in a wide range of climatic and environmental conditions (Mounir et al., 2015). Broad bean Vicia faba L. and snap bean Phaseolus vulgaris L. are essential leguminous crops in Egypt. Broad bean is one of the oldest crops and the third most important grain legumes in the country whereas snap bean is a pioneer export crop (Nassib et al., 1991; Anil et al., 2013).

Dipteran leafminers are insect herbivores whose larvae live inside plant leaflets, feeding on mesophyll tissue (Johnson et al., 1983; Parrella et al., 1985; Salvo and Valladares, 2007). Presently, more than 20 Liriomyza species of the family Agromyzidae (Diptera) are recorded as economically important pests (Spencer, 1972; Anonymous, 2009). The American serpentine leafminer L. trifolii (Burgess) is one of the most destructive pests for many vegetable crops, including bean crops, in the world (Spencer, 1972; Morgan et al., 2000). In Egypt, L. trifolii has been causing an economically significant loss and damage of many bean crops (Abul-Nasr and Assem, 1961; Shahein and El-Maghraby, 1988).

Many Liriomyza species have proved to show a host plant preference, and, hence, the infestation can depend on crop species and variety (Parkman et al., 1989; Zhao and Kang, 2001; Ueno, 2006; Tran et al., 2007). On the other hand, Liriomyza populations seasonally fluctuate and frequently differ in density among

1 Institute of Biological Control, Faculty of Agriculture, Kyushu University, Fukuoka 812-8581, Japan

2 Plant Protection Research Institute, ARC, Sakha, Kafr ElSheikh, 33516, Egypt

3 Economic Entomology Department, Faculty of Agriculture, Kafrelsheikh University, Kafr El-Sheikh 33516, Egypt

* Corresponding author (E-mail: ueno@grt.kyushu-u.ac.jp) regions because they can respond to changes in temperature, precipitation and other climate conditions (e.g., Tran et al., 2007). Thus, a number of biotic and abiotic factors may affect the severity of infestation caused by Liriomyza pests. However, the severity of leafminer infestation and factors influencing leafminer occurrence have not been studied thoroughly in Egypt.

The current study addresses the importance of leafminer management in bean production in Egypt by examining the severity of leafminer infestation on bean crops in Kafr EL-Shiekh Governorate. This study first shows the species composition, infestation level and population fluctuation of leafminers on bean plants in the Kafr EL-Shiekh region. Furthermore, our study focuses on how bean species, planting dates and weather factors could influence the infestation by the leafminers detected. We discuss the importance of Liriomyza control in bean fields.

\section{MATERIALS AND METHODS}

Field surveys were carried out to monitor agromyzid leafminers attacking broad and snap bean fields. For this purpose, three different fields of broad bean with different planting dates and one French bean field were selected, and field sampling was initiated from the earliest growing stage of beans in the four fields, and continued once per week until the beans were harvested. Sampling started when bean plants were one month old. Thus, sampling was done from 15/12/2015 to 15/03/2016, from 29/12/2015 to $16 / 03 / 2016$, and from 12/01/2016 to $22 / 03 / 2016$ for each of the three fields of broad bean var. Giza 3 and one field of snap bean var. Giza 6 from 15/12/2015 to 15/03/2016 in Kafr El- Sheikh Governorate.

For each sampling field, four points were selected randomly, and from each point 25 leaflets were collected. The cross-diameter method was used for collecting from 
each plant; from all different plant height levels one leaf each was picked out. The collection was made on a weekly basis. Collected leaflets were turned back to the laboratory, and the numbers of leafminer larvae were examined for each leaf; the numbers of empty mines were also counted. The sampled leaflets from each replicate were placed separately into Petri dishes $(10 \mathrm{~cm}$ diam.), and were kept in a growth chamber at $25 \pm 2^{\circ} \mathrm{C}, 70 \pm 5 \%$ $\mathrm{RH}$, with a photoperiod of 14:10 (L: D) $\mathrm{h}$ for the emergence of leafminer adults.

The samples in each Petri dish were checked every day for the emergence of leafminer pupae. When they were found, they were separated carefully from the leaflets, and transferred into a new Petri dish (10 cm diam.) to record their origin. The number of pupae from each replicate was recorded, and the Petri dish was then placed in the same growth chamber for further development into adults. The numbers of emerging adults of leafminers were checked and were then identified to the species level. Liriomyza spp. and Melanagromyza spp. were identified by the external morphology and male aedegous (Spencer, 1972). To examine the effects of two abiotic factors, i.e., temperature and rainfall, on leafminer populations, we calculated the average temperature and precipitation during 10 days before each collection date. Data were analyzed using JMP software (SAS Institute).

\section{RESULTS AND DISCUSSION}

In the current study, the majority of leafminers in our region were identified as Liriomyza trifolii, which was collected from all broad bean and snap bean fields surveyed. In addition, Melanagromyza phaseoli Coquillet were detected in French bean field though the density was very low. Liriomyza trifolii is known as one of the major dipteran leafminers attacking various vegetables and is distributed widely in the world, including Egypt (Spencer, 1972; Shahein and El-Maghraby, 1988; Anonymous, 2009). We also detected another dipteran pest, the bean fly $M$. phaseoli. This pest, also known as Agromyza phaseoli Coquillet, is recorded as the most damaging in the seedling stage of bean plants (Spencer, 1972; Webster and Parks, 1993). Below we mainly focus on $L$. trifolii rather than $M$. phaseoli because it was the major leafminer in our study.

The mean infestation densities represented by the mean numbers of viable larvae plus pupae per 25 sampled leaves in broach bean fields were 50.7, 41.2 and 44.8 for the field 1, 2 and 3, respectively while the infestation of snap bean (= French bean) was considerably low and the mean leafminer number was 8.0 in snap bean field (Fig. 1). The infestation densities were then statistically analyzed with a repeated measure ANOVA. The analysis revealed that the mean number of leafminers differed among the four fields (n = 196, $F=30$. 9, $P<$ 0.0001). The result may suggest that $L$. trifolii prefers broad bean to snap bean.

Proximal factors affecting host plant selection by leafminers are not well understood. In the present study, broad bean was significantly susceptible to leafminers

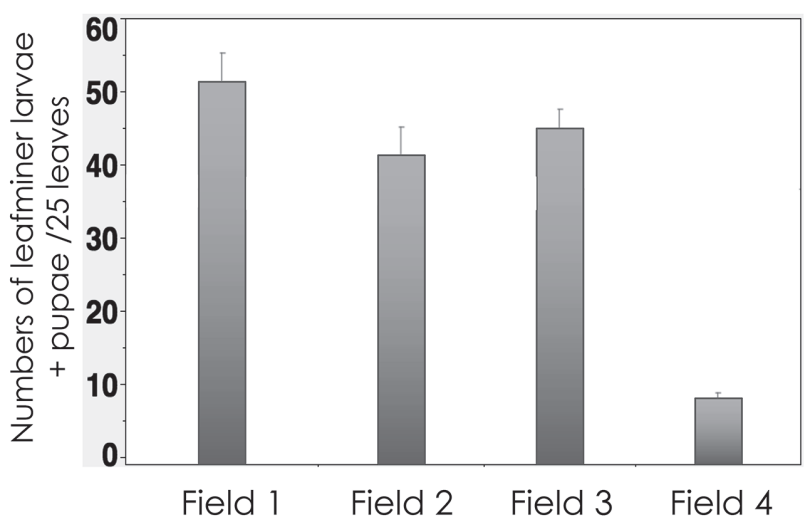

Fig. 1. The mean numbers $( \pm \mathrm{SE})$ of leafminers (larvae + pupae) per 25 bean leaves sampled. The first 3 fields were planted with broad bean and the last was with snap bean (French bean). See the text for details.

than French bean (Fig. 1). A possible explanation is that leaf moisture or water content of broad bean leaves is high. Wei et al. (2000) have demonstrated that high leaf moisture is the most significant factor positively influencing the development of L. huidobrensis and that the leaves of broad bean $V$. faba is the highest in leaf moisture among 47 species of plants examined. Similarly, L. trifolii may prefer water-rich broad bean as a host plant. Plant preference in leafminers will be a subject in our future study.

Agromizidae leafminers were detected in all study fields throughout the growing season and also showed great fluctuations during the growing season in all studied fields (Fig. 2 and 3). The proportion of bean leaves damaged by at least one leafminer tended to increase later in growing season of broad bean though infestation was high throughout the season in the field 3 (Fig. 2). This may be because empty mines have been accumulated among bean leaves, increasing the proportion of infested leaves. The mean number of leafminer larvae per leaf did not show a simple pattern, and the trend of fluctuations differed markedly among the sampled fields (Fig. 3).

Although we found that leafminer infestation varies in time and space, we do not know what biotic and abiotic factors could affect the leafminer populations. Knowing such factors should help constructing effective management tactics against leafminers in bean fields. Then, we examined possible factors affecting leafminer populations. In general, precipitation and temperature are major abiotic factors influencing insect populations. We suspected the two abiotic factors could affect the infestation by leafminers. Accordingly, we tentatively constructed statistical models (least square model) with three independent variables (precipitation, temperature and sampling date) and random effects (field, collection point) (in the model, we did not include the data from the snap bean field because leafminer density was uniformly too low). Although the model obtained was not perfectly reliable, the result suggested an involvement of rainfall in leafminer density. The model was highly significant 


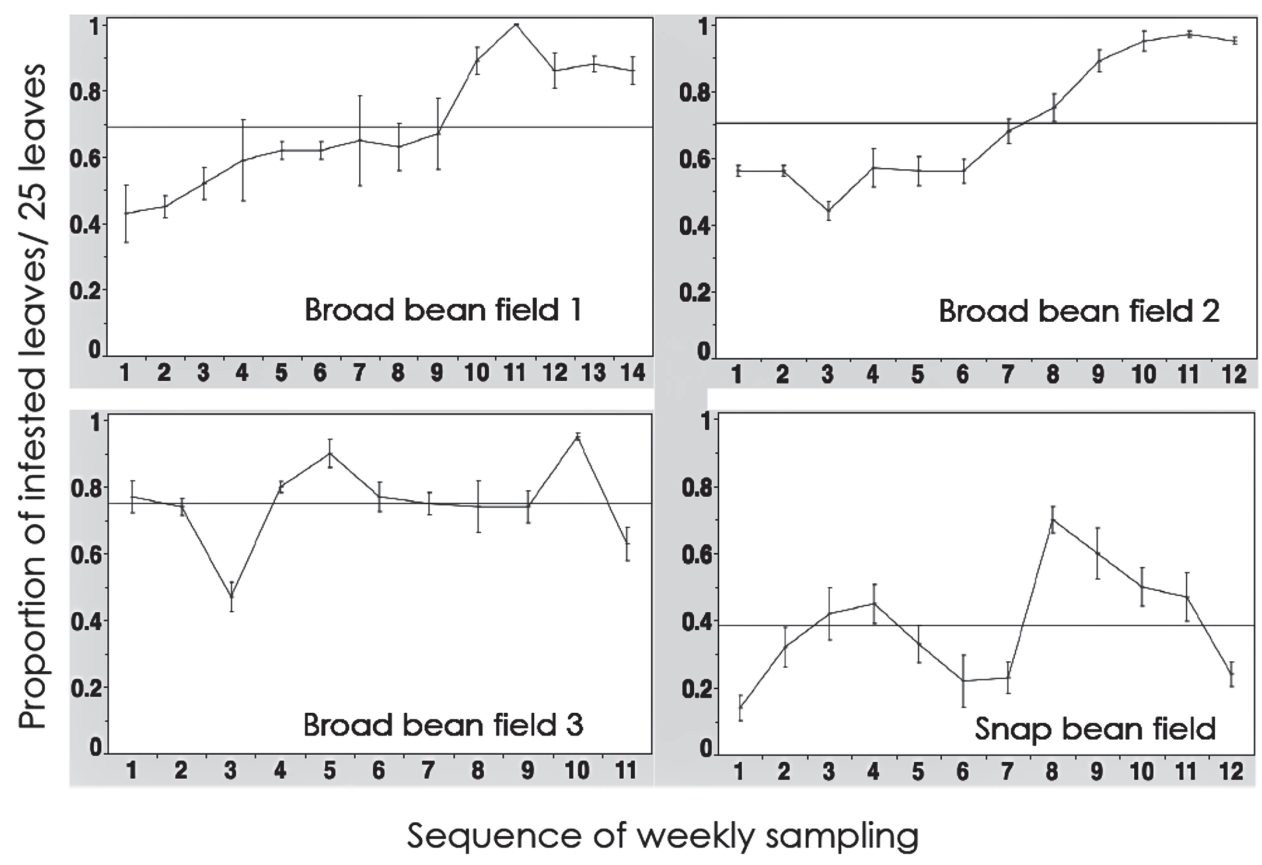

Fig. 2. The relationships between the sampling dates (weekly basis from Decempber, 2015 to March, 2016) and the proportions of bean leaves damaged by leafminers per 25 leaves sampled. Horizontal and vertical lines indicate the overall means and standard errors, respectively. See the text for details of the dates of sampling.

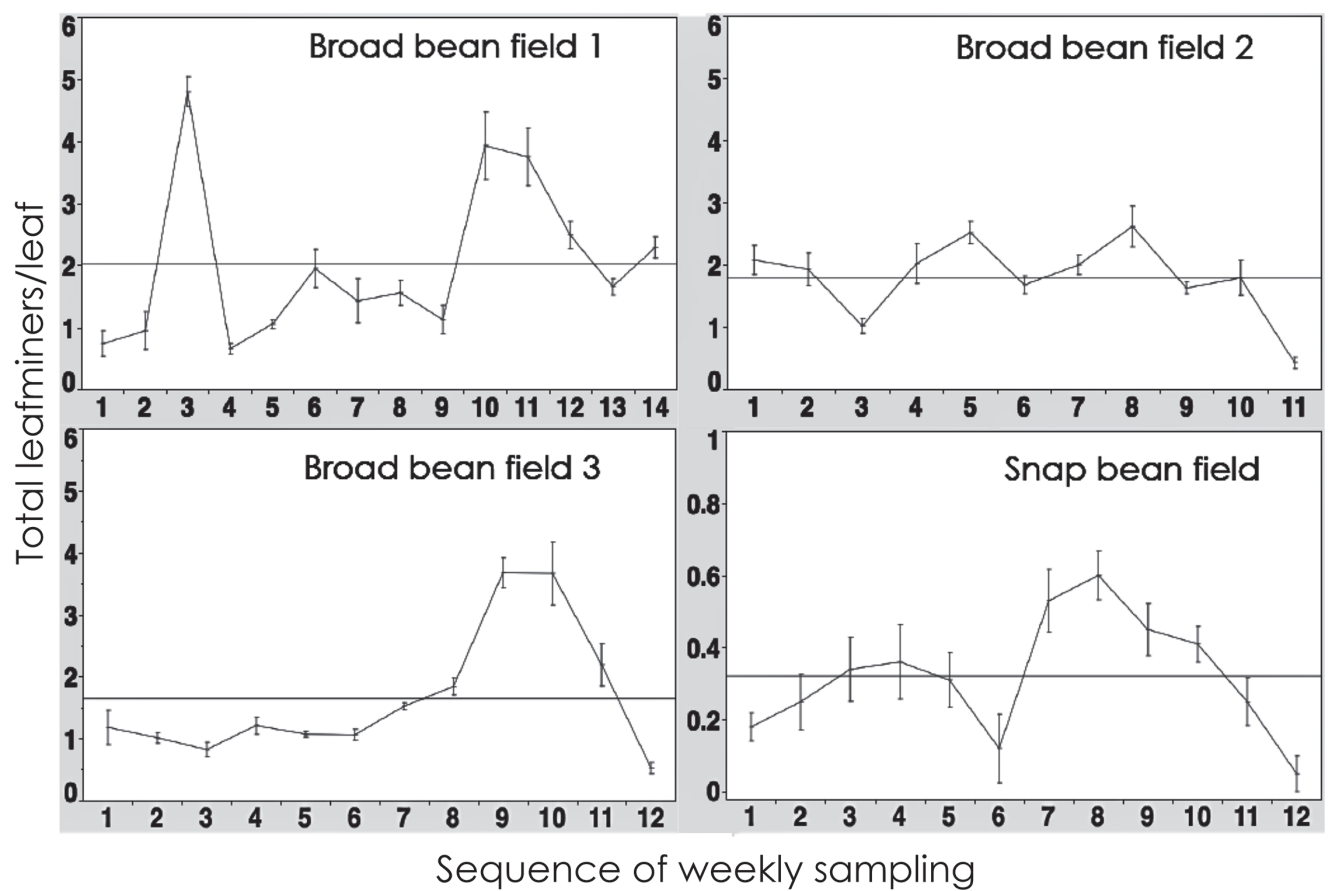

Fig. 3. The relationships between the sampling dates (weekly basis from Decempber, 2015 to March, 2016) and the total numbers of leafminers (larvae + pupae) per 25 leaves sampled. Horizontal and vertical lines indicate the overall means and standard errors, respectively.

(n $\left.=148, r^{2}=0.20, P<0.0001\right)$. Among the three fixed factors entered, precipitation was highly significant with a negative correlation $(F=13.1, P=0.0004)$, and temperature was slightly significant with a positive correlation. Unfortunately, the two factors mutually correlated $\left(r^{2}=0.35\right)$ and our data is limited in number, we just suggest the involvement of precipitation and temperature determining the level of leafminer populations.

In any case, the present results together with available literatures demonstrate the importance of leafminer 
control in bean fields. Leafminer infestation was considerably high throughout the growing season though, in our study, leafminer density was fairly low in snap bean. The current main measure to combat the leafminers is chemical control in Egypt. However, due to pesticide resistance frequently observed in Liriomyza leafminers (Salvo and Valladares, 2007; Liu et al., 2009), chemical control does not always work well. Alternative measures are hence on demand, and integrated pest management tactics are necessary for effective leafminer control.

Biological control with parasitoid wasps can be an effective measure to reduce leafminer damage (Salvo and Valladares, 2007; Liu et al., 2009). So far, many species of parasitoid wasps have been recorded from Liriomyza leafminers (e.g., Gates et al., 2002; Tran et al., 2007), and the parasitoid wasps adopt several foraging tactics to effectively hunt leafminers (Ayabe and Ueno, 2004, 2012; Ho and Ueno, 2008), making them effective natural enemies. In Egypt, likewise, some parasitoid wasps can be good candidates for biological control of leafminers (Shahein and El-Maghraby, 1988; Bassiony et al., 2017). Future studies should thus address how we can engage parasitoid wasps into leafminer control in Egyptian bean fields.

\section{AUTHOR CONTRIBUTIONS}

R. A. Bassiony designed and conducted the field experiments, analyzed the data, and prepared the first draft of the manuscript. F. A. Abou-Attia, M. A. Samy and A. E. Yousseft contributed in molding the research concept and also helped during the field surveys. T. Ueno discussed the results and polished up the research concept and manuscript.

\section{REFERENCES}

Abul-Nasr, S. and A. H. Assem 1961 A leaf miner, Liriomyza bryoniae (Kalt), attacking cucurbitaceous plants in Egypt. Bull. Entomol. Soc. Egypt, 45: 401-403

Anil K. S., R. C. Bharati, C. M. Naresh and P. Anitha 2013 An assessment of Broad bean (Vicia faba L.) current status and future prospect. African J. Agric. Res., 8: 6634-6641

Anonymous. 2009 List of pests recommended for regulation as quarantine pests. EPPO. http://www.eppo.org/ QUARANTINE/ listA2.htm

Ayabe, Y. and T. Ueno 2004 Directed search pattern of a leafminer parasitoid among mines of host larvae. Ann. Entomol. Soc. Am., 97: 586-591

Ayabe, Y. and T. Ueno 2012 Complex feeding tracks of the sessile herbivorous insect Ophiomyia maura as a function of the defense against insect parasitoids. PLOS ONE, 7: e32594

Bassiony A. R., F. A. Abou-attia, M. A. Samy, A. E. Youssef and T. Ueno 2017 Parasitoid wasps attacking the American serpentine leafminer Liriomyza trifolii in Kafr EL-Shiekh, Egypt. Int. J. Zool. Investig., 3: in press

Ho, T. H. G. and T. Ueno 2011 The effects of honey as a dietary supplement on the survivorship and nutrition-storing capacity of Hemiptarsenus varicornis (Hymenoptera: Eulophidae), a parasitoid of Liriomyza (Diptera: Agromyzidae) leafminers. Int. J. Trop. Insect Sci., 78: 78-84

Gates M. W., J. M. Hearaty, M. E. Schauff, J. B. Whitfield and D. B.
Wahl 2002 Survey of the parasitic Hymenoptera on leafminers in California. J. Hym. Res., 11: 213-270

Ho, T. T. G. and T. Ueno 2008 Host discrimination and factors affecting incidence of superparasitism in Hemiptarsenus varicornis (Hymenoptera: Eulophidae), a parasitoid of the leafminer Liriomyza trifolii (Diptera: Agromyzidae). J. Fac. Agric., Kyushu Univ., 53: 447-452

Johnson M. W., S. C. Welter, N. C. Toscano, I. P. Ting and J. T. Trumble 1983 Reduction of tomato leaflet photosynthesis rates by mining activity of Liriomyza sativae (Diptera: Agromyzidae). J. Econ. Entomol., 76: 1061-1063

Liu T. X., L. Kang, K. M. Heinz, and J. Trumble 2009 Biological control of Liriomyza leafminers: progress and perspective. $C A B$ Reviews: Perspectives in Agriculture, Veterinary Science, Nutrition and Natural Resources, 4: 1-16

Morgan D. J. W., S. R. Reitz, P. W. Atkinson and J. T. Trumble 2000 The resolution of California populations of Liriomyza huidobrensis and Liriomyza trifolii (Diptera: Agromyzidae) using PCR. Heredity, 35: 53-61

Mounir A. M., Abo El-Yazid A., Orabi I. O. A, Zahran A. A. and ElOksh 2015 Effect of sowing date, gamma irradiation and intracultivar differences on growth, pod characteristics and some endogenous plant growth regulators in snap beans. World J. Agric. Sci., 11: 380-390

Nassib A. M., S. A. Khalil and A. H. A. Hussein 1991 Faba bean production and consumption in Egypt. In "Present Status and Future Prospects of Faba Bean Production and Improvement in the Mediterranean Countries", CIHEAM, Zaragoza (Spain), pp. 127-131

Parkman P., J. A. Dusky and V. H. Waddill 1989 Biological studies of Liriomyza sativae (Diptera: Agromyzidae) on castor bean. Environ. Entomol., 18: 768-772

Parrella M. P., V. P. Jones, R. R. Youngman and L. M. Lebeck 1985 Effect of leaf mining and leaf's tippling of Liriomyza spp. on photosynthetic rates of chrysanthemum. Ann. Entomol. Soc. Am., 78: 90-93

Salvo A. and G. R. Valladares 2007 Leafminer parasitoids and pest management. Cien. Inv. Agric., 34: 167-185

Shahein A. and M. M. A. El-Maghraby 1988 Studies on the hymenopterous parasitoids of Liriomyza trifolii (Burgess) (Dipt., Agromyzidae) on broad beans in Egypt. J. App. Entomol., 106: $377-380$

Spencer K. A. 1972 Diptera. Agromyzidae, Handbooks for the Identification of British Insects. Royal Entomological Society, London (UK)

Tran D. H., T. T. A. Tran, L. P. Mai, T. Ueno and M. Takagi 2007 Seasonal abundance of Liriomyza sativae (Diptera: Agromyzidae) and its parasitoids on vegetables in southern Vietnam. J. Fac. Agric., Kyushu Univ., 52: 49-55

Tran D. H. and T. Ueno 2012 Toxicity of insecticides to Neochrysocharis okazakii, a parasitoid of Liriomyza leafminers on vegetables. J. Fac. Agric., Kyushu Univ., 57 $127-131$

Ueno, T. 2006 Current status of insect pests attacking green bunching onion in Central and Southern Vietnam. J. Fac. Agric., Kyushu Univ., 51: 275-283

Ueno, T. and D. H. Tran 2015 Neochrysocharis okazakii (Hymenoptera: Eulophidae) as a major parasitoid wasp of stone leek leafminer Liriomyza chinensis (Diptera: Agromyzidae) in Central Vietnam. Psyche, Article ID 179560

Webster, F. M. and T. H. Parks 1993 The serpentine leaf-miner J. Agric. Res., 1: 59-88

Wei J., Z. Li, R. Kuing and H. Liping 2000 Influence of leaf tissue structure on host feeding selection by pea leafminer Liriomyza huidobrensis (Diptera: Agromyzidae). Zool. Stud., 39: 295300

Zhao Y. X. and L. Kang 2001 Host plant preference of the polyphagous leafminers Liriomyza spp. Acta Entomol. Sinica, 44: $567-573$ 